\title{
Carry on Cabby, Gender, and the Local Industrial Power Nexus
}

\section{Kieron O'Hara}

More than 900 years have passed since the Norman Conquest, and it is sobering to think that so many centuries of English history, that the slow, beneficent growth of a society so traditional and stable, that the legacy of Shakespeare, Jonson, Dryden and the like-should have issued at last with "Carry On Camping," which opened yesterday at neighborhood theaters. ${ }^{1}$

For no man Laughs at old jests....

\section{Introduction}

The Carry On films have for a long time held an important place in British popular culture, although a place not acknowledged in the literature on popular culture as often 'as one might think. A series of comedy films played by a large ensemble of comedy actors, with little or no claim to art, whose humor would fairly be described as basic, the Carry Ons have a felt Englishness ${ }^{3}$ about them, often described as analogous to fish and chips, or saucy seaside postcards. They have not endeared themselves to critics or intellectuals: feminists and the right deplore their near-obsession with the breasts and bottoms of a series of buxom actresses (chiefly Barbara Windsor); the left detect reactionary views, ${ }^{4}$ particularly of working relationships, perhaps most in evidence in Kenneth Cope's doctrinaire and obstructive shop steward in Carry On At Your Convenience. Even where the influence of the Carry Ons is acknowledged without prejudice, it is not generally the case that that influence can be seen as a good one. For example, Peter Hutchings rightly notes the importance of the Carry On tradition for Hitchcock's Frenzy; ${ }^{5}$ however, no-one would claim that Frenzy was the most politically correct of Hitch's pictures. Hutchings makes the point that Frenzy was

...a reminder of what has been lost in [the renaissance of British cinema]broad comedy, horror, melodrama, and "bad taste" in general. The achievements of David Puttnam, Richard Attenborough and co. have been considerable, 
but a regeneration of British cinema must remain incomplete until those areas of cinema which have for so long underwritten the industry in terms of popularity have been acknowledged, not only in critical writing but also in the types of films that are being made. ${ }^{6}$

This paper should be seen in the context that Hutchings advocates.

We will argue that the perceived homogeneity of the mass of Carry Ons is, to some extent at least, an illusion (fostered, no doubt deliberately, by the fact that they all have the same actors, scriptwriters, titles, and even jokes). Hence, sweeping condemnations of the films as a group are misguided. We will argue that one film, Carry On Cabby, is actually premissed on a highly reasoned and sensitive analysis of Britain's post war industrial malaise and the effects of that malaise on the working class, together with a subtler than expected view of the way in which the post-war industrial situation affected relationships between the sexes. The theme of Carry On Cabby, as with so much post war British comedy, is "the battle of the sexes"; but it uses that standard to examine closely the need for change in industrial practice, taking a close look at the way in which change would affect the lives of "ordinary people." Its conclusions are pretty safe and pretty conservative-this is no radical political text! But its analysis proves to be more prescient than those of either the governments of the 1970s, which, roughly speaking, attempted to preserve the status quo, or Margaret Thatcher's radical Conservative government of the 1980s.

We look at Carry On Cabby in the later sections of the paper; we begin with a more discursive orienting section on the Carry On films in general. Readers familiar with the Carry On tradition may want to skip to section 3 .

\section{Background: the Carry On Films}

The Carry Ons began life with a "fast and friendly" farce "that should cause no pain", with a "humdrum script and slack direction saved by energetic performances". ${ }^{8}$ Carry On Sergeant was a version of R.F. Delderfield's play The Bull Boys, a routine service farce of incompetents coming good. No-one could have predicted the proliferation of Carry Ons from this beginning ("an unimportant import that does absolutely no harm"). In the end, there were thirty of them (with possibly more to come) all directed by Gerald Thomas and produced by Peter Rogers. Talbot Rothwell wrote more than his fair share. Many actors became highly associated with the series: Kenneth Williams, Sidney James, Barbara Windsor, Joan Sims, Jim Dale, Hattie Jacques, Kenneth 
Connor and Charles Hawtrey. ${ }^{10}$ Other regular players included, in approximate order of public association with the series, Peter Butterworth, Bernard Bresslaw, Jack Douglas, Liz Fraser, Dilys Laye, Angela Douglas, Amanda Barrie, Jon Pertwee, Esma Cannon, Bernard Cribbins, Peter Gilmore, Terry Scott, June Whitfield, Bill Owen, Windsor Davies, Eric Barker, Cyril Chamberlain, Michael Ward, Kenneth Cope, Richard O'Callaghan, Jacki Piper, Larry Dann, Terence Longden, Shirley Eaton and Judith Furse. Sometimes the occasional guest star would appear: Phil Silvers (Follow That Camel), Ted Ray (Teacher $\left.{ }^{11}\right)$, Juliet Mills (Jack), Harry H. Corbett and Fenella Fielding (Screaming), and Frankie Howerd (Doctor and Up the Jungle).

The thirty or so Carry Ons come in three phases, with a coda. These phases have sometimes been noted, but the trend is still toward treating all thirty (made, of course, over a long period of time) as instances of a stylistic unity. So, for example, Andy Medhurst notes a progression, but still suggests an all-purpose analysis for the series as a whole.

[They] began life as a one-off uniform comedy, Carry On Sergeant (1958), before growing into a once or twice per year institution that drove sensitive bourgeois critics to distraction and kept many Odeon cinemas in business. Staying in uniform at first (Nurse, Constable, Teacher), in the 1960s they found their richest vein in generic parody (Spying, Screaming, Cleo, Cowboy, Up the Khyber). Carry On films can be seen as slightly distant relatives of the variety tradition, principally through their tireless fixation on sexual innuendo. They lack any warmth or evocation of community, and rely on ensemble playing rather than the driving force of individual comic talents... By their increasing sexual directness, however, they put an end to the very traditions of innuendo that sustained them for so long. ${ }^{12}$

Here we see the threefold division (uniform/generic parody/increasing sexual directness) which I am going to urge in this section. However, still the search in the quoted paragraph is for points of similarity. These can, of course, be found (as one would expect in a series of films with the same actors, producer and director). But the net is spread very wide. They lack warmth (but what about Sergeant or Teacher?). They fail to evoke community (surely Teacher and Cabby should be exempt). They rely on ensemble playing rather than individual comic talents (well, Kenneth Williams had a tendency to take over, and Phil Silvers is the undoubted center of attention in Follow That Camel). And all these points apply just as neatly to the radio program Round the Horne and the T.V. program Monty Python's Flying Circus (both of whose increasing sexual directness also tended to dry up the innuendo market). 
The first phase of the Carry Ons involved mild parodies of various aspects of British life (not necessarily uniformed aspects), rather like highly anodyne versions of the series of Boulting Brothers' satires produced through the late fifties and early sixties. ${ }^{13}$ So, in this period we have (in sequence) Carry On Sergeant (army), Carry On Nurse, Carry On Teacher, Carry On Constable (police), Carry On Regardless (the "helping hands" odd jobs agency), Carry On Cruising (cruise liner) and Carry On Cabby (taxicabs). These films tend to be farces based around the idea of incompetents coming good (Sergeant, Constable, Regardless and Cruising). Nurse and Teacher are similarly based around slapstick and mayhem, but the premisses are slightly different. In Nurse, the relationship between the square pegs and the round holes is not one of authority as such; the patients are unable to conform to the almost military structure of the hospital. In Teacher, Ray is the popular headmaster in line for a promotion away from his school. The children in his charge realize that their good behavior is actually a precondition for that promotion to go ahead; they don't want to lose him, and so begin to behave badly (with predictable results) in order to ensure that he stays. In these films, there is a tendency for a shy lovelorn idiot (usually Connor) finally to impress the girl of his desire, perhaps by showing his true nature as opposed to the unreal show he tries to put on (with comic effect) during the course of the picture. Any double entendre is kept more or less firmly under control. Plot is of importance (Regardless is the exception here, which puts a number of sketches of incompetents at work into a very loose plot structure). There is a clear aim for the picture to be judged on its merits; the jokes and farcical situations are intended to be funny on their own terms. This is comedy to be taken at face value. In this last point, these films are at their most divergent from those in the later phases.

That these early Carry Ons were part of a lowbrow tradition of British comedy largely devoid of (or at least prior to) the surrealism and deliberate corniness of the classic period of the Carry On pictures is not a point that is well understood by critics. For example, in a number of regional issues of the Radio Times in 1993, Derek Winnert observed that the 1965 film The Big Job was more like an Ealing comedy than a Carry On. This analysis is clearly false (although it is arguably the case that it is more like an Ealing comedy than, say, Carry On Cleo). The Big Job would and does sit well with early Carry Ons such as Cabby or Sergeant. It was produced by Rogers, directed by Thomas and scripted by Rothwell, and included roles for James ("Professor Hook"), Sims and Dale (plus a minor role for Ward). "Doctor Line" was played by Dick Emery, a comedian best known for his television work; he never played 
in a Carry On, but was on the fringe of that tradition (he moved from the Goonish humor of the fifties ${ }^{14}$ through to a type of humor more recognizable as Carry On-compatible in the seventies ${ }^{15}$ ). The inevitable "Mr. Sinker" was played by Lance Percival (who had had a central role in Carry On Cruising as the seasick cook). Plot featured strongly; it was the old one about the bank robber who, released from jail, returns to where he stashed the proceeds, only to discover that a police station has been built around it. ${ }^{16}$ Lots of items familiar from everyday life are used for comic effect; for example, when sent out to nick a telescope to observe the police station, "Mr. Sinker" brings back a "pay as you view" telescope from the park-the crooks' observations keep being interrupted by the need to put a tanner (6d) in the slot every few minutes (an instantly recognizable frustration for anyone who has ever used one). Although the ensemble playing is not played up to the usual Carry On standard, we do get several views of the caper (the views of the crooks, which predominate, but also the views of the women and those of the police), and conversely some Carry Ons also play down the ensemble (e.g., Jack, Emmanuelle). In fact, one is tempted to think that the only reason this was not one of the early phase Carry Ons was that it was difficult to think up a natural enough Carry On title (Carry On Burgling, Carry On Robbing Banks-no, no, no). On the other hand, the distance between The Big Job and Ealing is massive on any metric.

Phase two of the Carry Ons is focused on parodies of films or film genres. So here we have Carry On Jack (Hornblower), Carry On Spying (James Bond), Carry On Cleo (Cleopatra), Carry On Cowboy (Westerns), Carry On Screaming (horror, especially Hammer), Follow That Camel ${ }^{17}$ (Beau Geste), Don't Lose Your Head ${ }^{18}$ (French Revolution), Carry On Doctor ${ }^{19}$ (medical), and Carry On Up The Khyber (Northwest Frontier). Here we get the development of the Carry On style as it is most commonly perceived. We have atrocious puns:

Julius Caesar (Williams): Infamy! Infamy! They've all got it in for me!

Cleo

Rumpo Kid (James):

Belle (Sims):
So you're Belle?

Yeah, but ma intimate friends call me "Ding-Dong."

Cowboy

Duc de Pommefrite (Hawtrey): Desirée (Sims):
There is a beautiful spot in the arbour.

Oh really? I had no idea we were so near the sea. 
There are plenty of silly names: in, for example, Cleo,$^{20}$ we have Hengist Pod, ${ }^{21}$ Bilius, Sosages, ${ }^{22}$ and two partners in the slave trade called Marcus et Spencius. Other characters have quite sensible names the point of which is purely to provide a cheap gag later on. ${ }^{23}$ For example, we have a slave girl Gloria, ${ }^{24}$ which enables Caesar to say, when he is seasick, "I'm a little sic transit, Gloria," and a galleymaster Agrippa, which licenses this dialogue:

Agrippa (Francis de Wolff): Hengist:

\section{I'm Agrippa.}

And I know one or two holds myself, so you wanna watch it, mate.

This use of comic names tends to distinguish this middle phase from the early phase, where the characters tended to have slightly exaggerated names perceived as "working class"-Bert, Sid, Charlie, etc..

Double entendre runs riot, even in the title of Carry On Up The $K_{\text {Khber }}^{25}$. The foreign legionnaires in Follow That Camel travel to Fort Soixante-Neuf. In Screaming, there is a repeated confusion when the suspect is asked "How far did you get [into the woods]?"- - the answer comes back "Not very far, Doris and me aren't married." Khyber, Sir Sidney Ruff-Diamond (James) has "tiffin"27 with a succession of beautiful girls. Jack gives us this dialogue:

Albert (Cribbins): $\quad$ Albert Poop-Decker's got a mole on his....

Capt. Fearless (Williams): On his...? On his what?

Albert:

Well, it's just on his, sir.

Fearless:

Oh, I see. [To Sally] Well, have you got a mole on yours?

Sally (Juliet Mills): On my what, sir?

Fearless:

Yes, on your wotser.

Highly ingenious moments provide the viewer with simultaneous examples of all three items, such as in the opening lines of $U p$ The Khyber:

Lady Ruff-Diamond (Sims, looking at Williams, playing the Khasi of Kalabar):

'Oo's the turbanned job on the throne?

Sir Sidney: You mean the Khasi. ${ }^{28}$

Finally, there are many moments of anachronism. Sir Sidney and Lady Ruff-Diamond's ceremonial elephant has a GB sticker on its rear, while $\mathrm{Cleo}$ has the following interchange between its leading characters:

Seneca, Caesar's Father-In-Law ${ }^{29}$ (Hawtrey): Caesar:
Beware the ides of March.

Oh shut up, you silly old faggot $!^{30}$ 
Calpurnia, Caesar's Wife (Sims):

Caesar: [wearily]
Don't you dare speak to my Daddy like that!

Well he gets on your nerves. ${ }^{31}$

Gradually, through this phase of the Carry Ons, the importance of plot and character diminishes under the weight of these comic imperatives. The jokes themselves cease to be funny as jokes-they are amusing because they are uttered. We, the audience, are invited to admire the sheer brass neck of anyone shameless enough to deliver such lines, and the sheer single-mindedness of plots whose sole intention is to allow scope for double entendre, pun, anachronism. By the time $U p$ The Khyber has been reached, practically every single proper name has become improper. Apart from the merely punnish Sir Sidney and Lady Ruff-Diamond, ${ }^{32}$ we have: the Khasi, the Princess Jelhi, ${ }^{33}$ Major Shorthouse, ${ }^{34}$ Pte. Widdle, Brother Belcher and Bungdit Din, the leader of the deadly tribe of Burpas. The plot, such as it is, involves the British regiment the 3rd Foot and Mouth, defending the Khyber Pass, and their only being able to do this by wearing kilts with nothing on underneath, thereby terrifying the Burpas ("with their great things waving at you") in the heat of battle. When evidence arrives that members of the 3rd Foot and Mouth wear underpants, the Burpas are persuaded to revolt. Clearly, this makes practically no sense whatsoever, and is there primarily as a vehicle for our admiration as a machine for the conveyance of resolutely bad jokes to an audience.

The third, degenerate, phase, involved both social and generic parody, and was marked by the tendency noted by Medhurst to push against boundaries of good taste that had already virtually ceased to operate. In this phase we have Carry On Camping; Carry On Again, Doctor; Carry On Loving (marriage bureau); Carry On Up The Jungle (Victorian exploration of Africa); Carry On Henry (Henry VIII); Carry On At Your Convenience (industrial relations in a toilet factory); Carry On Matron (more medical); Carry On Abroad (British holidays on the Mediterranean coast); Carry On Girls (beauty contest); Carry On Dick (Dick Turpin); Carry On Behind (caravanning); Carry On England (WWII) and Carry On Emmanuelle (Emmanuelle). In these films, the jokes get steadily bluer (in Emmanuelle, even Concorde gets an erection), and the nudity gets more explicit (Barbara Windsor's breasts appear first in Camping and her bottom in Again, Doctor, we get both in Abroad, and a whole parade of topless female soldiers in England). Some of the gags and situations, even in unfunny films, are inevitably amusing, if only in the bare-faced cheek sense we outlined earlier. For example, At Your Convenience involves a strike at the toilet factory of W.C. Boggs \& Son, while Abroad involves the following exchange: 
Farquhar (Williams): My name is Stuart Farquhar.

Pepé (Butterworth): Stupid what?

However, in the main, Medhurst's judgement quoted above is difficult to gainsay.

A final burst of life for the Carry On films came as they moved into fashion again (after some fourteen years) thanks to a new generation of scatological comedy in Britain, taking over from the Oxbridge style of Monty Python's Flying Circus/Not the Nine O'Clock News. In 1992, Carry On Columbus (starring Dale) was made to cash in on the Columbus quincentenary. Time will tell whether public interest is sufficient for the series to be extended still further; however with Williams, Hawtrey, James and Jacques now dead, Connor and Sims established on television in senior roles, and Windsor, though still striking, being unlikely to continue to base her career on flashing her unmentionables, it is difficult to see how that could be.

\section{Carry On Cabby}

We will now focus on Carry On Cabby, both as an indicator of how varied the Carry Ons could be, and as a demonstration that it is not necessarily the case that the Carry $O n$ s are reactionary and single minded; in particular, we will argue that Cabby gives a highly sympathetic, uncoloured and even-handed portrait of the state of gender and labor relationships in the early 1960s. In this section, we give an account of the film and its plot; in the final section, we will discuss issues raised by its treatment of these relationships.

\subsection{Credits}

Carry On Cabby was a Peter Rogers production, (c) Anglo Amalgamated Film Distributors Ltd. 1963. The main cast was:

$\begin{array}{ll}\text { Charlie Hawkins } & \text { Sidney James } \\ \text { Peg Hawkins } & \text { Hattie Jacques } \\ \text { Ted Watson } & \text { Kenneth Connor } \\ \text { Terry "Pint Pot" Tankard } & \text { Charles Hawtrey } \\ \text { Flo Sims } & \text { Esma Cannon } \\ \text { Sal } & \text { Liz Fraser }\end{array}$

Other regulars involved were Owen, Furse, Barrie, Chamberlain, Gilmore, and Ward, and, in his first Carry $O n$, Jim Dale has a small part. ${ }^{35}$ The other credited actors are Milo O'Shea, Ambrosine Phillpotts, Renee Houston, Carole Shelley, Norman Chappell, Noël Dyson, Michael 
Nightingale, Ian Wilson, Peter Byrne, Darryl Kavann, Peter Jesson, Don McCorkindale, Charles Stanley, Marion Collins and Frank Forsyth. The screenplay was by Talbot Rothwell, based on an original story by S.C. Green and R.M. Hills, ${ }^{36}$ Morecambe and Wise's early scriptwriters. The music was composed and conducted by Eric Rogers, another Carry On regular. The art director was Jack Stephens; the director of photography was Alan Hume. Finally, as ever, the picture was produced by Peter Rogers and directed by Gerald Thomas.

\subsection{Plot}

In the opening scene, Charlie is driving a cab. Back at the garage, Peg is looking for Charlie-he has promised not to go "cabbing," because when he does she never sees him. Pint Pot arrives and causes an accident - the first of many. He is looking for a job-he is ex-army, and he has heard that Charlie likes to look after "the boys." Charlie's manager Ted takes him on, despite his accident-proneness. Pint Pot indiscreetly reveals to Peg that Charlie is out cabbing-and it is Peg and Charlie's anniversary. Peg calls Charlie on the cab radio; he claims he is only out to get her a present, and buys her a fur coat. She has to pay, because she has custody of all their money. She has bought him a smoking jacket, pipe and slippers, ready for the cottage which he has promised to buy when they have children. At this he runs away back to work to avoid the issue.

Peg meets Sal, the proprietress of the garage canteen, and they complain about the excessive work put in by Charlie and Ted, who is Sal's fiancé; they agree that Charlie and Ted should take them out into London for a night out. However, Smiley Sims (Owen) hasn't turned up yet, ${ }^{37}$ so Ted agrees not to go out that night and to take Smiley's bookings. Charlie will take a fare to the airport and still have time to be back for seven, when they are due to go out. Ted breaks the news to Sal, who tries to break her china over his head.

On the way back from the airport, Jeremy (Dale) stops Charlie and insists that he take Jeremy's pregnant wife to the hospital since she is in labor. Charlie's radio is on the blink and can't tell Peg. Jeremy's wife has a succession of false alarms, involving Charlie driving backwards and forward between Jeremy's house and hospital until the baby is finally born half way between, with a district nurse (Dyson) as midwife, late at night. Peg and Sal get drunk together in the meantime. Charlie gets home at 12:30, and sleeps on the sofa.

Next morning, Peg announces that she is going to get a job. Charlie is against it, but he has to leave to settle an industrial dispute. Allbright (Chappell) successfully objects to Flo, Smiley's wife, taking on his cab 
for the day, because she is a woman. Peg meets with Flo, and makes a (secret) offer. They rent a yard, and buy fifteen Ford Cortinas. Charlie is seen waking after Peg has gone to work, at seven, and going to bed before she gets home at 11:35. Peg and Flo are seen choosing a series of beautiful girls. Meanwhile Charlie is having a terrible time, being unable to cook or keep house. This goes on for two months; Ted and Sal aren't talking either.

Unbeknownst to Charlie, Peg and Flo have set up a rival taxi service called "Glamcabs." The drivers are all beautiful women; the Cortinas all have heart-shaped lights; Peg poses as "Mrs. Glam." Before they start, she is already worried about the effect this new venture will have on her husband, but Flo and Sal tell her that the men are merely getting a taste of their own medicine. The Glamcab drivers soon take all the business away from the male drivers by using their sex appeal. Charlie tries to undercut them; tries to steal their business by tuning into the frequency of the Glamcab radios; tries to sabotage their cabs. He fails every time, partly because Sal and Peg are taken into Ted and Charlie's confidence about the schemes, and partly because of the goodwill of the (male) passengers towards their (female) drivers.

Peg determines to tell Charlie two things, but before she can, Charlie tells her of his plan to sneak into the Glamcab yard and put all their cars out of action ("no rough stuff and no real damage"). The plan is that Ted is sent into the yard dressed up as a Glamcab driver. Flo, tipped off, calls all the Glamcab drivers in to change their uniforms. Ted, confronted with all the women in their underwear, and asked to strip, runs away and hides. ${ }^{38}$ The women are ready when he lets the men in, and they set the car wash hoses on them.

Next day, Charlie is beaten, and goes to the Glamcab yard with Ted to admit defeat and agree to sell out to Mrs. Glam. He sees first Flo, then Sal, and then Peg. Ted and Charlie then walk out. Peg is hopeful for a reconciliation, but they don't meet for a month.

Then Peg and Sal go to take the day's takings to the bank, when they are kidnapped in one of their cabs by a gang of thugs (led by Gilmore). Meanwhile, Charlie has taken to drink and is letting his firm go down. Peg turns on the radio in her cab, which is monitored by Sarge (Chamberlain). Charlie, miraculously sober now, apprehends the situation, and marshalls his cab drivers by radio to force the stolen cab onto the heath, which, after a few mishaps, they do. The crooks are cornered and captured by the cab drivers. Peg faints; Sal tells Charlie that Peg is pregnant, upon which he faints too. Married bliss is restored at the end. 


\section{Discussion}

Clearly this picture is largely concerned with the "battle of the sexes"-men's and women's roles are clearly featured throughout. ${ }^{39}$ However, the interesting point about this theme is that it is intertwined tightly with the contrast between the "old" and the "new," as symbolized by the conflict between the "draughty old cabs" and the brand-new Glamcabs. The hackney cabs are traditional, staid, over-practical, whereas the Glamcabs are prettily painted Ford Cortinas, ${ }^{40}$ with seductive drivers. But the film, though clearly supporting the proposition that the old ways could not go unchanged, is also very sympathetic to the forces of conservatism in the workplace. The subliminal message of the film is: change, but not unrestricted flux.

\subsection{Charlie's Cab Firm}

We can begin our discussion by looking at Charlie's cab firm. The nature of Charlie's firm, and the cabbies, is demonstrated in the first scene in the picture. After a credits sequence following Charlie's cab around town, the opening dialogue is the following:

[Charlie's cab pulls up at traffic lights in the left hand lane, next to a chauffeurdriven Rolls-Royce. Charlie reaches out of his window and polishes the Rolls' radiator grille. Chauffeur looks at him disdainfully.]

Charlie: Wotcha, mate?

[Chauffeur looks away.]

Charlie: Oy, where's the funeral then? [Looks at the middle-aged lady in the back of the Rolls.] Watch it mate, she's got out of the box. [Laughs. $]^{41}$

[The lights change. Charlie turns right from the left hand lane, cutting up the Rolls, causing it to stop. Charlie pulls over.]

Charlie: Don't do that when you take your test, mate. You'll never pass.

[Lady looks as him through lorgnette.]

Lady: $\quad$ You filthy rotten roadhog.

Charlie: Good for you, lady. [Laughs and drives off.]

In that scene, we see virtually all the characteristics of the traditional old firm displayed. The cabbies are abusive and drive in a manner which could fairly be called inconsiderate. There is almost a sense that cab drivers should turn right from the left hand lane, even if the right hand lane were free. This is a good old comic cliché about taxi drivers (one that is often borne out by one's personal experience); they abuse traffic laws with relative impunity, and are mildly astonished at the thought that traffic laws are to be obeyed by cabbies at all. Further, their cavalier attitude 
is extended to their customers. In a scene in which Charlie is training his new drivers, he asks Len (O'Shea) to plan a route from A to B. When Len suggests a straight route down the High Street, Charlie is shocked by this suggestion, and, on the basis that a cabbie never goes straight anywhere, plots a route that goes the long way round. ${ }^{42}$

On the other hand, the cabbies have a strong sense of their own worth, as against that of authority. In the opening scene, Charlie is more than willing to recognize the quality of the Rolls-Royce next to which he has parked. But when the chauffeur rejects the overture, Charlie is not prepared to take this lying down-he is as good as the other chap-and he cuts the Rolls up at the lights. Of course, he probably would have done this anyway, since he couldn't have known the reception he would get when he took the left hand lane; however, now he could turn right and hurl abuse at those who look down upon him. When the lady leans out of the Rolls and gives him a mouthful, he is quite happy with thatas long as the interaction is one between equals. Hence the cabbies' practices provide a crucial sense of identity for the drivers, and a sense of a role in society - senses which get undermined by the intervention of the women.

\subsection{Charlie}

Charlie himself personifies most of the qualities of his firm. The picture is at pains to point out that Charlie himself is a fundamentally decent bloke. He loves his wife-there are numerous indications of that. On a small scale, the registration number of the first cab he owned is PEG 1 (the cab is known as "Peg"). On a more important level, he only started his cab firm as a way of building up enough money to afford a cottage where he and Peg could bring up their children. This was a commitment given by Charlie to Peg in the early days of their marriage. However, they now spend a lot of their time arguing about the correct interpretation of that pledge. Charlie's view is that the pledge entails that when Peg has children, the surplus money will be used to buy the cottage, whereas Peg's idea is that, when sufficient funds to buy a cottage are available, the cottage should be bought, whereupon she would provide the children to populate it. Now that sufficient funds are available, the rival interpretations are in conflict. Charlie clearly isn't interested in money - he barely spends any, and when he realizes he has forgotten their anniversary, he doesn't worry about buying a fur coat. What has come to happen is that he has grown to identify himself not with his family but with his work. The means, as so often, have become the end, and Peg's vision of marital bliss now seems tame compared with the pleasures of cutting up Rolls-Royces at traffic lights. 
However, Charlie does have a residual regard for alternative values and value-systems. For example, he appears to employ anyone from his "old mob," i.e., his old unit in the army - even Pint Pot, who spends the first half-hour of the picture causing accidents, and can't drive. He doesn't forget old colleagues, clearly. And this attachment to his military past is, of course, a great aid during the final chase after the kidnappers. ${ }^{43}$ Further, he is also supportive of the principle of women cab drivers. When Flo wants to take Smiley's cab out, he is quite willing to see the common sense of this - better that the cab be used than lie idle. He supports Flo as far as he can, but when Allbright threatens a strike, he doesn't protest when Flo gives up her attempt.

But he certainly can be hypocritical in the event that alternative values conflict with his own, and is prepared to cheat in order to gain advantage, while still representing it, to himself at least, as an intrinsic advantage of his male-oriented cabbie existence. For example, after sabotaging one of the Glamcabs, he offers a lift to the stranded passenger with the words: "That's the trouble with these fancy jobs-you can't rely on them." The passenger, of course, is much happier repairing the Glamcab. Earlier, Charlie has been monitoring Glamcabs' radio messages; Flo responds by sending the Hawkins cabbies on wild goose chases. Charlie rationalizes his tactical defeat as follows:

Charlie:

Well, it's obvious, innit? Somebody has tipped them off that we're poaching their orders.

Pint Pot: Yes. Ooh, there aren't half some dishonest people about, aren't there?

Charlie: $\quad$ Yeah. But what can you expect from a bunch of birds?

In short, Charlie is a decent chap who has lost the wider view. He cannot see that his tactics are neither fair nor honest; he cannot see that he has more responsibilities than those to his firm (and drivers); he cannot see that his gains in cab driving are smaller than his losses in his marriage. What he needs is some kind of shock, and this is what the Glamcab enterprise provides. Peg can see all this from her standpointand is the only character who realises quite how painful the change is going to be for Charlie and the other men.

The same considerations apply, mutatis mutandis, to Ted in his relationship to Sal. Sal is not as bright as Peg, but has the same instinctive grasp of the "right" order of things.

Ted: Oh, Charlie, please! That's no way to handle women.

Charlie: Hark who's talking! What about you and Sally? 
Ted: Well, that's different, innit? We're not even married. Anyway, I gave her a bloody good talking to, and we've reached an understanding.

\section{Charlie: And what's that?}

Ted: [sadly] I don't know. We're not even talking to each other.

Note that, in this exchange (conducted against the background of a classically untidy kitchen of which Charlie has been unable to keep control), Ted gets to use the only swear word in the film. Swearing, we are reminded on a couple of occasions, is a male preserve; Ted's swearing seems to suggest both his male view of the way to "handle women," and the crudeness of the attempt, which ultimately dooms it.

\subsection{Allbright}

In contrast to Ted and Charlie, the pernicious effects of the old order are represented by Allbright, the shop steward. Apart from the young thugs who kidnap Peg and Sal, Allbright is the closest that the picture comes to a villain. He is a union man, who interprets everything that occurs through the union rulebook; in consequence, he is often obstructive, and incapable of seeing the "non-cabbie" point of view. His subservience to the rules mean that he sacrifices advantage for the 1960 s version of "political correctness."

In one example of this, he objects to Flo taking Smiley's cab out; although the chief gain from this is Charlie's, it is also true that Smiley will suffer, and Allbright, who after all is charged with Smiley's protection as a member of the union, will be depriving him of his pay (although of course, other drivers may have gained overtime). However, union rules say no women in cabs, and that's that. Similarly, Allbright objects to the number of ex-servicemen being employed by Charlie; Ted responds "Well, alright then. Now, before Charlie started, there wasn't a regular cab service in this town. Now we've got forty, employing twenty regular drivers." Clearly the implication is that the town's drivers are better off with Charlie and his ex-servicemen than without. Allbright has tunnel vision, is ludicrous in his slavish obedience. Why can't women drive cabs? Because in the first place, the men would have to mind their language, and in the second place, there's only one W.C. To which Flo replies that, in the first place, she had forgotten more language than Allbright ever knew, and in the second place, she doesn't want to go in the first place. In the film's climax, Allbright plays his part in the rounding up of the kidnappers, but warns "I don't know what the union's gonna say about this!"

An interesting factor in all this is Allbright's sexual ambivalence. Norman Chappell is an adept in playing a kind of lower-middle class 
camp-a stereotype known as the "mummy's boy"-and the entry of this factor into the equation is of note. After Flo has given up her attempt to drive Smiley's cab, Allbright and Ted have an exchange.

Ted: Alright, Mr Allbright?

Allbright: No. I like a good fight. You gave in much too easily.

Ted: [winding the cab window shut on Allbright's head] Oh, I bet you say that to all the girls.

- the joke, of course, being that he doesn't say it to any girl. At the close of the film, Len looks benignly at two smoochers in the back of his cab; Allbright's expression is one of horror. When the Hawkins drivers realize how threatened they are by the Glamcab drivers, they go to Ted to complain. Len's testimony as to the beauty of the Glamcab drivers results in a "Don't be disgusting" from Allbright; when Ted suggests sending the drivers out in tight skirts and falsies, Allbright's response is "Don't be so common," while holding together the lapels of his coat defensively.

Hence the clear implication is that the unfettered pursuit of the cabbie way of life, intransigent and unpragmatic-as symbolized by the union rulebook - in fact leads to the perversion of normal social roles. This picture doesn't appear opposed to homosexuality per se-in one scene, Michael Ward (an actor adept at upper class camp) gets out of Ted's cab; Ted notices something on the back seat and calls Ward back. "Is this your pearl earring, sir?" he asks. Ward looks at him with surprise: "What, with tweeds?" Ted is lost for words, but there is no assumption that Ward's character will bring down all of civilization by his addiction to the love that dare not speak its name. Homosexuality in the abstract is, in a 1960s British comedy, a massive joke of course, but not necessarily a wrong thing. However, it is certainly wrong for good strapping working class lads like Charlie, Ted, Len et al. ${ }^{44}$ Allbright serves as an awful warning that, if you identify yourself too closely with your job you will cease to be able to have a "normal" sex life at home. Charlie and Ted nearly fall victim.

\subsection{Sex and Double Entendre}

This being 1963, the normal sex life is rather more in the mind. Of the double entendres in the picture, about half, in the nature of the case, are to do with sex. Ted asks Sal in the canteen for a fourpenny roll.

Sal: I wish I had a nice big spanner.

Ted: $\quad$ So do I. I'd soon get you loosened up a bit. 
However, the extent of Ted's sex life appears to be his trying to pinch her walnut crackle in the cinema. Sex before marriage is not really on the cards - there are many jokes about what the honeymoon couple who Charlie takes to the airport will be doing on their honeymoon, and Charlie intervenes when Pint Pot calls a pregnant woman "miss." Similarly, the male passengers who are most excited by the Glamcabs drivers are content to sit and look (often from under the cab up the short skirt of the Glamcab uniform).

Peg: $\quad$ Right girls, this is it. I want you to get out there and grab all the business from under their smug male noses. I don't care how you do it-within reason. Just get the fares in your cabs. [Glamcab driver giggles.] Er, in the back of the cab, dear, with you in the front. Any questions?

Anthea (Barrie): Well, actually, darling, d'you think we really stand a chance? I mean, there are far more men drivers, actually.

Peg: I know, but the men haven't got your advantages, dear. Just flash your headlamps at 'em.

Sex with the drivers is obviously not within reason!

However, half the double entendres being sex-related entails that half aren't, and, in contrast to a third-phase (or even a second-phase) Carry On, that is a very even proportion. There is a tentative sequence about pregnancy, as Charlie and Pint Pot drive Jeremy and his pregnant wife into the maternity hospital:

Pint Pot: Wait a tick, we're going the wrong way.

Charlie: He said turn in and go straight up to the front.

Pint Pot Oh yes, but on the board it said all deliveries round the back.

Charlie: Here we are then.

Jeremy: It's all right. It was a false alarm.

Charlie: What?

Jeremy: We can go home now. Oh yes, she said, would you mind hur rying? She's got something in the oven.

But mainly the other jokes are about toilets and swearing, ${ }^{45}$ e.g.:

Ted: My advice to you is to be off.

Pint Pot: $\quad$ You mean buzz off?

Ted: $\quad$ No, but you're getting warm.

These double entendres suggest, not illicit sexual activity (as is the case with both earlier ${ }^{46}$ and later ${ }^{47}$ generations of British comedy), but 
merely vulgarity-bodily functions that we all know that we all carry out, without mentioning them, and curses, which again, everybody knows but is afraid to utter.

In consequence, we can see that the danger of becoming another Allbright in the service of Hawkins cabs is not a physical problem but a psychological one. Part of the identity of the men involves their swearing, lusting after women, etc.. Allbright simply is not vulgar enough to support that sort of characterization; he has "gone all genteel" and has stopped talking about toilets (he is the only person to refer to a toilet with an accepted term-W.C.). Even in an all-male working environment, other identities are essential for true English vulgarity to flourish.

\subsection{The Shock of the New}

And into the world dominated by this weird weltanshauung come the Glamcabs. Glamcabs really do represent what is considered to be the future. Pragmatic, and willing to give up outmoded traditions for current gain (e.g., hackney carriages for Ford Cortinas), they quickly take over the town's cab business. They even ban tipping-much to the shock of the men. Who wouldn't choose a Glamcab over a Hawkins cab? Well, actually, a woman might not, but there don't appear to be any female cab passengers in the town at all. In fact, the Glamcabs' impact seems to stem from their being situated in a "man's world."

Nevertheless, they are a symptom of the inevitable progress of industry to a Post-Ford era (ironically driving Cortinas). The traditional mentality symbolized by Hawkins cabs is a tender thing that can be swept away by anyone prepared to cater for more modern requirements, and how prophetic that seems now in the $1990 \mathrm{~s} .{ }^{48}$ But, as Peg realizes, how unfortunate to those people whose livelihoods and, more importantly, identities, are wrapped up in the "old ways." These old ways are dying, and are defenseless against rational change, says the film, but that change needs to be humanely applied. Peg is driven to force change in order to get the traditional family life that she has always wanted-in this sense, the arrival of Glamcabs on the scene is unequivocally the fault of the men-but sees the inevitable disturbance as something from which few will benefit. ${ }^{49}$

An interesting effect of the climax is the link between these new working practices and an increase in crime. Aside from the petty sabotage that the Hawkins drivers get up to, there is no pathological wrongdoing. But more symbols of the modern age are crammed into the climax. The kidnapping is part of the brutality of the modern era. Three young thugs speed up in a modern Jaguar; they have guns; they kidnap two defenseless women. Gilmore's characterization of the leading thug is strongly reminiscent of the young psychopathic villains that Derren 
Nesbitt was portraying about that time..$^{50}$ Compare that with the bank robbery in The Big Job, which is nostalgically set in a flashback in 1950 . James apparently has a gun - but in fact it is a cigarette lighter. No harm is done to anyone; no harm, of course, results from the modern day robbery and kidnapping, but these modern criminals take risks that will inevitably lead to injury or death on some occasions. ${ }^{51}$

\subsection{Conclusions}

Carry On Cabby gives us a view that is a relatively sane (within the constraints of postwar British comedy), conservative, view of social change. The subliminal message underlying the film is a plea for sanity as the world begins to change rapidly in the white heat of Prime Minister Harold Wilson's technological revolution. Britain, of course, wasn't quite so sane in the event. The 1970 s were largely devoted to preserving unprofitable, outmoded and socially damaging ways of life; the 1980s were largely devoted to sweeping them aside, at appalling human cost. It is, of course, difficult to imagine Margaret Thatcher watching Carry On Cabby-perhaps Britain would be less a less divided nation if she had.

The film does come down squarely on the fence with respect to most of the issues. It ends happily with Peg and Charlie reconciled; however, it has been quite plainly established that there is only room in the town for one cab service, and there is no indication of which cabbies will lose their jobs. One suspects it will be the females. Similarly, in the end, neither Charlie's nor Peg's interpretation of his vow to her (to buy a cottage for the kids) is vindicated by events-with the baby on the way, both interpretations of the vow entail that the cottage should now be bought. Nevertheless, this is a comedy entertainment, not political tract. What it demonstrates is a series of oppositions in action in British life which politicians have failed to reconcile as efficiently as Carry On Cabby has.

What it further demonstrates for the film critic is the interest that lies in these B movies. As we suggested earlier, Carry Ons are often pigeonholed together in a dusty corner; but Cabby has points of interest that belie the suggestion that it shouldn't be regarded as a film individually. ${ }^{52}$ Our introduction defended the premiss that "bad taste" films of this sort were being overlooked in favor of the work of the Puttnam/ Attenborough school of filmmaker; the aim of the sequel is to provide an illustration of how these films, which generally made money, of course, can be of interest to modern eyes. 


\section{Notes}

'Roger Greenspun. Review of Carry On Camping. New York Times 24 Feb. 1972.

${ }^{2}$ Thomas Hobbes. Leviathan I 6.

${ }^{3}$ Not particularly a felt Britishness.

"' 'Carry On Camping'...really does require a settled social system, a widely accepted code of conduct, a set of values, an appreciation of class and the accents of class - all of which may be ridiculed with the complete assurance that nothing will be touched." Greenspun op cit.

5Peter Hutchings. "Frenzy: a Return to Britain" in All Our Yesterdays: 90 Years of British Cinema. Ed. Charles Barr. London: B.F.I., 1986. 368-74.

${ }^{6}$ Ibid. 374.

${ }^{7}$ Howard Thompson. Review of Carry On Sergeant. New York Times 28 Oct. 1959.

${ }^{8}$ Leslie Halliwell Halliwell's Film Guide.

'Thompson op cit. Little did he know!

${ }^{10}$ Hawtrey and James were the only ones with lengthy cinema experience. Hawtrey had acted as a juvenile alongside Will Hay in the thirties and forties, including a starring role in The Ghost of St. Michael's, whereas James (who was actually South African) had been turning up more or less frequently in British movies, sometimes as a gravelly cockney (The Titfield Thunderbolt, The Lavender Hill Mob), sometimes as an American (Orders Are Orders, The Glass Cage)-though he also worked on radio (Hancock's Half Hour). Williams remained associated rather more with radio (Round the Horne, Hancock's Half Hour, Just a Minute). Dale had been a pop star (Be My Girl, The Piccadilly Line). Jacques did a lot with radio (ITMA, Hancock's Half Hour), but is also to be seen in a number of bit parts in film (Scrooge), Sims also (The Belles of St. Trinians). Some of them moved into television. Connor has recently completed the run of 'Allo 'Allo, and Sims is becoming increasingly ubiquitous in sitcoms. Before their deaths, James and Jacques starred in, respectively, Bless This House and Sykes.

"In general, reference to a Carry On film in this paper will drop the "Carry On." This causes no ambiguities (i.e., I won't be referring to a film called Teacher). All the Carry Ons are listed later in this section.

${ }^{12}$ Andy Medhurst, "Music Hall and British Cinema" in All Our Yesterdays: 90 Years of British Cinema. 168-88, 182-83.

${ }^{13}$ Institutions parodied by John and Roy Boulting included the army (Private's Progress, 1956), the law (Brothers in Law, 1957), industry and the trade unions (I'm All Right Jack, 1959) and the church (Heavens Above, 1963).

${ }^{14}$ E.g., the short The Case of the Mukkinese Battle Horn, with Peter Sellers and Spike Milligan. 
${ }^{15}$ E.g., Ooh You Are Awful (U.S. title Get Charlie Tully), about a small-time master of disguise and conman who has to discover the number of a Swiss bank account which is tattooed on the bottoms of four different women.

${ }^{16}$ The deficiencies of modern Hollywood were highlighted when a big budget version of this old chestnut was made with two big stars, Clint Eastwood and Jeff Bridges, in 1976 (Thunderbolt and Lightfoot). The point about using hackneyed plots is that you don't need to spend a lot of money on them. The only difference between, say, the Saturday morning serials of the thirties and forties, and Raiders of the Lost Ark is the outlay. Since the big problem facing the film industry today is the massive amount of investment required as compared to the uncertainty of the proposition, this is obviously the wrong direction to go (of course, Raiders of the Lost Ark did the business at the box office, but equally Big Trouble in Little China didn't). Two cheers to filmmakers who go back to styles of filmmaking that were actually popular, thereby rekindling what was a popular art form; they miss their third cheer by attempting to convert more or less routine, big-studio-based pictures using a cast of studio repertory artists, into big budget spectaculars, thereby turning a pretty safe, if unambitious, moneyspinner into a gamble for megabucks.

${ }^{17}$ More than an honorary Carry On. Produced by the Rothwell-ThomasRogers partnership, it was actually rereleased as Carry On Follow That Camel, a title which barely makes sense. It conformed perfectly to the second phase Carry On model, and involved Williams, Dale, Butterworth, Angela Douglas, Gilmore, Hawtrey, Sims and Bresslaw.

${ }^{18}$ Similar considerations apply as apply to Follow that Camel, apart from the fact that Carry On Don't Lose Your Head makes even less sense. Participating regulars included Williams, Butterworth, James, Dale, Gilmore, Hawtrey, Sims and Ward. Williams exhorts his executioner to "Carry on choppin'!"

${ }^{19}$ Of course, a medical comedy can be classed both a social parody and as a genre parody.

${ }^{20}$ Where, of course, scriptwriter Rothwell was constrained by having at least some characters created for him by Shakespeare and Shaw.

${ }^{21}$ This name is a creation of rare beauty and almost mathematical precision. Not only does it enable a half-remembered and anachronistic chord from British history to be struck when Hengist (Connor) teams up with Horsa (Dale), the name "Hengist Pod" also recalls "Genghis Khan" (a gentleman very unlike Connor's cowardly idiot), and gives a gag for free when it is revealed that Hengist's wife is called Senna.

${ }^{22}$ Pronounced "Sos-AH-ges"-which doesn't prevent Antony calling him Bangers.

${ }^{23}$ Senna Pod being one.

${ }^{24}$ Who, being buxom, quite naturally comes from Bristol. "Bristols" is a rhyming slang term for breasts (Bristol City $=$ titty). 
${ }^{25}$ In rhyming slang, "Khyber" referes to the backside (Khyber Pass = arse). Of course, the very term "carry on" implies saucy wrongdoing (as in "what a carry on!"). This presumably was fortuitous, given that the title of the opening picture in the series Carry on Sergeant also makes perfect sense as a typical army utterance.

${ }^{26}$ Exactly the same gag is used in Cabby.

${ }^{27}$ i.e., a light lunch.

${ }^{28}$ Both "throne" and "carsie" or "carsey" mean "toilet."

${ }^{29}$ Sic.

${ }^{30}$ In the British sense of "git" rather than the American pejorative term for a homosexual.

${ }^{31}$ Sometimes the joke is with misplaced accuracy. In Cleo, a legionnaire marches his men with the lines "Sinister, dexter, sinister, dexter...."

${ }^{32}$ Plus a couple of minor characters, Capt. Keene and "Ginger" Hale.

33" "Jellies" being yet another term for breasts.

${ }^{344}$ "Shorthouse" is a bowdlerization of "shortarse," a short person.

${ }^{35} \mathrm{~A}$ gag of which Talbot Rothwell would be proud.

${ }^{36}$ Though the climax bears a very strong resemblance to an Insignia Films production of 1954, Radio Cab Murder, produced by George Maynard, directed by Vernon Sewell, and starring Jimmy Hanley and Lana Morris. That film was devised by Vernon Sewell and Pat McGrath, from an idea by Donald Rawlings and Michael Storm, and written by Vernon Sewell.

${ }^{37}$ Actually, all the action so far has taken place on the same day, and Smiley was clearly seen in the canteen while Ted and Sal were talking, so we must suppose that he had been taken ill.

${ }^{38}$ This is one of the oldest comic situations in British films. It generally appears in a medical context, with a woefully ignorant and sexually terrified man moving into a nurse's hostel, for instance, Hawtrey in Again, Doctor, and Cope in Matron. It dates back much further than the Carry Ons, of course; for example, Will Hay in 1941's The Black Sheep of Whitehall is put in the same predicament ("Do you work with outpatients?" "No, always with."). Non-nurse versions include Bresslaw posing as a beauty queen in Girls and a scene in Ooh You Are Awful, where Emery is disguised as a policewoman; he is neither ignorant nor sexually terrified, however. An interesting variant in the Carry On series involved Sally in Jack disguised as a British sailor trying to take a bath on board ship in front of the all-male crew, which also exploits an ancient theme in English folk tales (cf. Fidelia in William Wycherly's The Plain Dealer of 1677).

${ }^{39}$ Rather like The Big Job, in fact.

${ }^{40} \mathrm{At}$ the time the Cortina had just appeared as Ford's mid-range vehicle, aimed at the market between that for the Anglia and that for the Classic. It was very fashionable in 1963 (and indeed has remained so). 
${ }^{41}$ James' laugh is a lewd-sounding growl that, when this film was being made, was on its way to becoming one of the icons of British comedy.

${ }^{42}$ In Charlie's defense against the previous charge of lawlessness, he goes on to criticize Pint Pot's route as being multiply illegal. However, the function of this exchange is more to demonstrate Pint Pot's incompetence than Charlie's devotion to the Highway Code.

${ }^{43}$ This is the theme of the climax of Radio Cab Murder, too.

${ }^{4}$ Hawtrey's character, of course, is more than a little camp, and occasionally, jokes about his potential homosexuality are made in Carry On films. However, the usual way with Hawtrey in the Carry Ons is to make his characters sex mad (Cleo, Camping). Cabby goes out of its way to show Pint Pot's heterosexuality.

${ }^{45}$ Sometimes, instead of double entendre, we get a character mumbling a swear word while the soundtrack gives us some other noise (e.g., feedback off the radio). This is another old standby-Gordon Harker used to use that gag a lot.

${ }^{46}$ E.g., George Formby, Max Miller, Ronald Frankau and their ilk.

${ }^{47}$ E.g., second and third phase Carry Ons, Up Pompeii, Dick Emery, or the Two Ronnies.

${ }^{48}$ Note also that Hawkins is a service firm, not a manufacturing firm.

${ }^{49}$ The symbolism of the film for forces at work in contemporary Britain is heightened by the use of locations, realistically shot by the photographic director Hume. The small town setting in the West of London (references to the Aldershot Road, to the airport-i.e., Heathrow, a road sign for the A308 to Maidenhead) is one instantly recognizable to a large number of urban-dwelling Englishmen.

${ }^{50}$ E.g., The Man in the Back Seat.

${ }^{51}$ This is the theme of a number of the Derren Nesbitt pictures.

${ }^{52}$ Actually, initially Cabby wasn't going to be one of the Carry Ons-this is why it is the only one until England without Williams in it-and its working title was Call Me a Cab. However, the fact remains that Rogers and Thomas did eventually incorporate it into the series, which of course prevents the argument from being undermined. Jack is another example of a film joining the stable late.

\section{Works Cited}

Greenspun, Roger. Review of Carry On Camping. New York Times 24 Feb. 1972.

Halliwell, Leslie. Halliwell's Film Guide. London: Granada, 1986.

Hobbes, Thomas. Leviathan. Harmondsworth: Penguin. 
Hutchings, Peter. "Frenzy: a Return to Britain." All Our Yesterdays: 90 Years of British Cinema. Ed. Charles Barr. London: B.F.I., 1986. 368-74.

Medhurst, Andy. "Music Hall and British Cinema." All Our Yesterdays: 90 Years of British Cinema. Ed. Charles Barr. London: B.F.I., 1986. 168-88.

Thompson, Howard. Review of Carry On Sergeant. New York Times 28 Oct. 1959.

Kieron O'Hara has a D.Phil. in philosophy from the University of Oxford, and is currently a researcher in the Artificial Intelligence Group at the University of Nottingham. He is interested in the application of philosophical techniques to criticism, and has had papers published in a wide range of journals, including The Malcolm Lowry Review, The Dickensian, Mind and Language, Mind, The Notre Dame Journal of Formal Logic and The International Journal of HumanComputer Studies. He is the co-editor of Advances in Knowledge Acquisition (Springer-Verlag 1996). 